\title{
Career attitudes and subjective career success: tackling gender differences
}

Mihaela Enache, Jose M. Sallan, Pep Simo and Vicenç Fernandez Departament d'Organització d'Empreses, Universitat Politècnica de Catalunya, Terrassa, Spain

\begin{abstract}
Purpose - The purpose of this paper is to analyze the effect of gender upon the relation between protean and boundaryless career attitudes and subjective career success, in today's dynamic and changing organizational context.

Design/methodology/approach - Data were collected using a questionnaire conducted on 150 graduate and post-graduate distance learning students. The data were analyzed using structural equation modeling.

Findings - The analysis indicates that women's career success is positively related with self-direction and negatively related with their reliance on their own values. Furthermore, the authors found a negative relation between organizational mobility preference and men's subjective career success.

Research limitations/implications - A potential limitation of this study is that all participants were distance-learning students, thus limiting the generalizability of the findings to other populations. Furthermore, cross-sectional designs do not permit drawing conclusions regarding the causal direction.

Practical implications - Organizations should transform work structures and human resources policies and provide career models that allow women flexibility and more control over their work. Research results show that values-driven predisposition may lead to low levels of perceived career success. This indirectly suggests that individuals experience intrinsic career success when their values are consistent with organizational values, and therefore they should seek work opportunities in organizations whose aim, scope, and philosophy is consistent with their ideals.
\end{abstract}

Originality/value - This is the first paper to shed light on gender's impact upon the relationship between protean and boundaryless career attitudes and subjective career success, in a context in which there have been calls in literature for more career research taking into account gender differences.

Keywords Gender, Career development, Self development, Spain

Paper type Research paper

\section{Introduction}

Until recently, the traditional career advancement model, emphasizing full-time, long-term organizational employment, and extensive commitment to one's organization, served as the backdrop for most research on careers (Valcour and Ladge, 2008). However, sweeping changes produced within the context of the knowledge-driven economy (e.g. globalization, rapid technological advancements, organizational downsizing, constant competitive pressures, democratization of work life (Gratton and Ghoshal, 2003), decrease in job security (Cappelli, 1999), increased workforce diversity, expanding use of outsourcing and part-time and temporary employees (Sullivan and Baruch, 2009), and increasing reliance on the dissemination and application of intellectual capabilities (Powell and Snellman, 2004) for creating and sustaining competitive advantage) have gradually reshaped the world in which careers are unfolding. 
In addition to these environmental changes, individuals are also changing their attitudes and behaviors in response to many factors, including increasing lifespans and work lives; changing family structures, including the increasing number of dual-career couples, single working parents, and employees with eldercare responsibilities; and the growing number of individuals seeking to fulfill needs for personal learning, development, and growth (Hall, 2004; Sullivan, 2010). All these factors determine individuals to initiate self-directed (SD) careers (Tharenou, 2009) or choosing lateral, or even downward, job moves to fulfill personal needs (Hall et al., 2008), being more motivated by their own desires and wishes, rather than organizational career management arrangements (Sullivan and Baruch, 2009). Moreover, transitions from the relational to the transactional psychological contract (Rousseau, 1989; Rousseau and Wade-Benzoni, 1995) have emphasized the active role of the individual in managing his or her own career and vocational destiny, and some researchers have offered concept of the boundaryless (Arthur, 1994; DeFillippi and Arthur, 1996; Arthur and Rousseau, 1996) and the protean (Hall, 1976, 2002) career as alternative perspectives to the traditional career model. Boundaryless careers refer to careers that are not bounded to a single employment setting, and that are "independent from rather than dependent on traditional career arrangements" (Arthur and Rousseau, 1996, p. 6). The term "protean career" derives from the mythological Greek God Proteus, who was able to change his form at will (Hall, 1976) and suggest that individuals can also reshape and adapt their career to face different life circumstances. Individuals embracing protean careers display self-directedness and a "values-driven (VD) attitude" that serve as an "internal compass" for them to successfully navigate their careers. Finally, boundaryless career is built around two axes, emphasizing both psychological and physical mobility (boundaryless mindset (BM) and organizational mobility preference (OMP)).

In spite of the fact that Briscoe et al., have made efforts to provide conceptual clarity among the protean and boundaryless dimensions, "they tend to be interpreted simplistically and at times too intertwined as symbols of the new career" (Briscoe and Hall, 2006, p. 5). As little empirical research has been drawn to support the theoretical propositions around protean and boundaryless delineations (Segers et al., 2008), several authors (Briscoe et al., 2006; Eby et al., 2003; Sullivan, 1999; Sullivan and Arthur, 2006) called for research taking into account gender, age, education, and other individual and cultural differences, which are hypothesized to influence the protean and boundaryless career attitudes. Finally, Sullivan and Baruch (2009) assert that there are conflicting results as to whether there are gender differences in the protean career orientation (Agarwala, 2008; Ng et al., 2008).

In tandem with an overall shift of gender composition of the workforce, women have increasingly gained entry to what there were once exclusively male career paths (Blau et al., 2002). Thus, how career paths may differ by gender is an issue that deserves future exploration (Valcour and Tolbert, 2003). The shift away from the organizationally defined careers to the individually defined careers has highlighted the importance of the subjective aspects of the career that refer to the individuals' own perceptions and interpretations of their career situation (Greenhaus, 2002). In a context in which individuals may embrace more idiosyncratic and heterogenous career paths, characterized by career discontinuities, lateral or even downward moves in order to meet work and non-work balance and psychological meaningful work, career success is likely to be disconnected from accomplishments within a hierarchy. Thus, it becomes more salient to assess it as reflected 
within the eye of the career actor (Hall and Chandler, 2005), due to the fact that a boundaryless career is believed to intensify the need for using internal (psychological), self-generated guides in defining one's career success (Mirvis and Hall, 1994).

All the above changes produced in the contemporary workplace and in individual attitudes point to the need for a better understanding of the determinants of subjective career success and for more attention to the impact of gender variables on individuals' satisfaction with their professional careers. The main objective of this paper is to explore gender differences among protean and boundaryless dimensions and their relation with subjective career success. We will start defining the two career models in more detail by describing their underlying attitudes. Hereafter, we will match career success to these attitudes according to gender and build hypotheses that will be tested by means of hierarchical regression analysis. Finally, results are discussed, together with implications, limitations, and directions for future research.

\section{Review of the literature}

The boundaryless career

The traditional career was defined in terms of progressive lineal advancement in one or two organizations and was conceived as evolving through a series of stages towards a pinnacle of power, income, and prestige within the hierarchical organization (Levinson, 1978; Super, 1957). By contrast, the boundaryless career metaphor highlights an independent, individually driven, and subjectively addressed career concept (Arthur and Rousseau, 1996), transcending the boundaries of a single employment setting. Although in the previous years some authors have approached boundaryless careers uniquely considering physical changes in work arrangements (Jones, 1996; Saxenian, 1996), Sullivan and Arthur (2006) emphasize the complexity of the boundaryless career concept and, thus, the need of viewing mobility as measured along two continua (physical and psychological), in order to fully capture the meaning of career boundarylessness. These authors identified six different meanings of the boundaryless career, arguing that it is a complex concept that, apart from emphasizing inter- and intra-organizational mobility, encompasses careers that can be extrapolated to employees' perceptions of the desirability or instrumentality of increased mobility (Feldman and Ng, 2007), involving careers:

- like the stereotypical Silicon Valley career, that move across the boundaries of separate employers;

- like those of academics or carpenters, that draw validation - and marketability - from outside the present employer;

- like those of real-estate agents, that are sustained by external networks or information;

- that break traditional organizational assumptions about hierarchy and career advancement;

- that involve an individual rejecting existing career opportunities for personal or family reasons; and

- that are based on the interpretation of the career actor, who may perceive a boundaryless future regardless of structural constraints.

The majority of studies examined mobility across physical boundaries (Sullivan, 1999). The physical mobility prevailed over the psychological one mainly due to the difficulty 
arisen when measuring individuals' perceptions of their capacity to make transitions (Sullivan and Arthur, 2006). Recognizing that a boundaryless career attitude is primarily psychological, Briscoe et al. (2006) provided empirical evidence, supporting for the existence of two boundaryless career attitudes: BM and OMP. Briscoe et al. (2006) defined a BM as a general attitude of transcending organizational boundaries, by feeling comfortable in interacting with people from different organizations and seeking out opportunities for experiencing new situations that result beneficial for the individual (e.g. providing the opportunity to enhance knowledge and skills). They refer to $\mathrm{BM}$ as the willingness "to initiate and pursue work-related relationships across organizational boundaries" (p. 31) from a set location. Holding a BM might result in the development and enhancement of the so-called knowing-whom competencies (Arthur et al., 1999; Defillippi and Arthur, 1996), which provide access to the resources other people possess, representing a source of expertise, reputation development and learning (Arthur, 1994; Defillippi and Arthur, 1994; Parker and Arthur, 2000). Moreover, Eby et al. (2003) found that knowing-whom predictors (i.e. the extensiveness of networks within and outside the organization, as well as mentoring relationships) are salient predictors of subjective career success.

The second boundaryless career attitude makes reference to the inclination of the individual towards physical mobility. In that sense, OMP describes individual's strength of interest of remaining with a single or multiple employers. A person high on such an organizational mobility attitude "would be comfortable with or even prefer a career played out across several employers" (Briscoe et al., 2006, p. 31). Organizational mobility can be motivated by an individual's pursuit of new learning and personal growth opportunities. Inter-organizational mobility is also associated with increases in salaries (Lam and Dreher, 2004), because individuals are reluctant to change jobs unless a noticeable pay rise occurs. Many individuals, who feel unsatisfied with their level of income or internal promotion, seek out higher income levels or promotion opportunities in the external market and frequently take them when offered ( $\mathrm{Ng}$ et al., 2005). Therefore, in spite of the fact that a high-mobility preference is associated with future significant increase in subjective career success, when having a cross-sectional approach, it can be argued that individuals look for opportunities beyond organizational boundaries when they are not satisfied with their current achievements in their employing organization.

Sullivan and Arthur (2006) argue that men are more likely to have greater opportunities for physical mobility whereas women are more likely to have greater opportunities for psychological mobility, as a result of social and psychological differences. Owing to family obligations, women may have less freedom than men to engage in physical mobility. However, they are inclined to build careers that are more relational based (Mainiero and Sullivan, 2005) and are more driven by the variety in their work (Inceoglu et al., 2008). Warr (2008) found that more men than women made positive ratings of good pay, a responsible job, and good chances of promotion. On the other hand, significantly more women than men rated as important pleasant people to work with, convenient working hours, and meeting people, thus exhibiting a higher psychological mobility than men:

H1. There is a positive relation between holding a BM and subjective career success, more intense in the case of women.

H2. There is a negative relation between OMP and subjective career success, more intense in the case of men. 
Within the context of a protean career, individuals, rather than their employing organizations, become the architects of their own careers, development and vocational destiny. This orientation represents an internally driven and SD perspective in managing one's career that reflects values such as freedom and adaptability (Hall, 1976, 2002). Similarly, a protean career was described as a contract with oneself, rather than with the organization, as individuals take active responsibility in managing their careers and transforming their career path (Baruch, 2004). Thus, the hallmarks of a protean orientation are: freedom and growth, professional commitment, the attainment of psychological success, through the pursuit of meaningful work and the discovery of a "calling" (Hall, 2004; Hall and Chandler, 2005). Moreover, it has been argued that taking responsibility for managing one's career development can deliver positive psychological outcomes, including career and life satisfaction, enhanced self-efficacy and well-being, as well as extrinsic career progression if desired career outcomes are achieved (Crant, 2000; King, 2004; Seibert et al., 2001).

Briscoe et al. (2006) identified two protean career relevant attitudes: SD career attitudes and VD predispositions, and developed scales for measuring them. Self-direction refers to an individual's self-reliance and proactive approach for managing his or her career (developing goals, searching for opportunities, taking responsibility for one's one success or failure, acquiring and developing skills and competences), instead of passively relying on the organization to provide him or her a clear career path. King (2004) argued that taking responsibility for managing one's career development can deliver positive psychological outcomes, including career and life satisfaction, enhanced self-efficacy and individual well-being, if desired career outcomes are achieved. Moreover, Seibert et al. (2001) and Crant (2000) found that individuals who have a proactive disposition achieve extrinsic career progression and internal satisfaction with their careers.

Apart from holding a proactive, SD approach in career management, protean career actors are VD in pursuing meaningful career goals. These individuals are motivated to shape their careers around their values, motives, and needs, instead of borrowing external standards (e.g. outcomes determined by organizations or society) for navigating their own careers (Briscoe et al., 2006; Hall, 2002). This sense of reliance on one's own values, highlighting the importance of one's own needs, dreams, and aspirations, is oriented towards the attainment of meaningful outcomes for the individual.

In terms of gender, early research indicated that women supposedly are encouraged less strongly to seek autonomy and are constrained more to affiliate with others from a subservient position (Lykes, 1985). As a result, it has been argued that self-direction values show a gender difference favouring male preference (Prince-Gibbson and Schwartz, 1998). However, the SD nature of a protean career often results in multiple career cycles of career exploration, learning and mastery (Hall, 2002) which permit a greater accommodation of family responsibilities. Women may go through numerous cycles as they seek to create careers that satisfy their own personal needs and definition of success (Valcour and Ladge, 2008). As opposed to men, women's definitions of career success often focus on subjective rather than just objective outcomes (Lirio et al., 2007; Sturges, 1999; Pachilicz et al., 2008; Valcour and Ladge, 2008; Wise and Millward, 2005), because they generally have more non-work responsibilities than men, making it difficult to adhere to the norms of the traditional career model. In protean careers, career success is internal, based on one's personal values. Psychological success, such as 
a sense of personal accomplishment or family happiness, is valued over more traditional measures of success like monetary rewards or progression up the corporate ladder (Cabrera, 2009). Defining success subjectively based on fulfilling personal values allows women to experience psychological success, even if they do not achieve more traditional measures of success. That is because women's career success outcomes are affected by their interactions with others in the workplace as well as by their own assessments of how well they are meeting work role expectations (Valcour and Ladge, 2008):

H3. There is a positive relation between self-direction and subjective career success, more intense in the case of women.

H4. There is a positive relation between VD and subjective career success, more intense in the case of women.

\section{Method}

Sample

Research data were collected using a web-based survey. The questionnaire was sent to 434 Spanish graduate and post-graduate distance-learning students of the psychology, business administration, humanities, communication, and law degrees. All the participants were employed at the time when the study was conducted. The participants represented a diverse set of industry sectors, such as agriculture (2 percent), industry (26 percent), building (9.33 percent), and service (62.67 percent). An introductory letter of invitation was sent by e-mail to the study participants. This invitation letter explained the purpose and significance of the study, emphasized voluntary participation and anonymity, and provided a hyperlink that took the participants to the survey web site. The participants were asked to visit the survey web site to fill out the questionnaire. Some days later, a postcard reminder was sent to the emailing addresses of the participants. The postcard reminded potential participants of the survey and encouraged them to participate in the study by using the hyperlink provided in the postcard reminder. Finally, 167 surveys were submitted by the respondents, representing a response rate of 38.48 percent. After handling the missing data, 150 usable entries had been obtained.

The respondents ( 58.00 percent women and 42.00 percent men) were anonymous and they were employed at the time the study was conducted. The average age of the respondents was 30.95 years old. As regards the organizational size, most of them (44.00 percent) were working for small companies, whereas only a 13.33 percent were working in middle-size companies and a significant percentage (42.67 percent) were employees of large companies. The average professional experience was 9.91 years $(\mathrm{SD}=6.86)$, with an average organizational tenure of 5.20 years $(\mathrm{SD}=5.44)$. Gender demographics is provided in Table I.

\section{Measures}

Protean career attitudes (self-direction in career management and VD predispositions) were measured using Briscoe et al.'s (2006) eight-item scale (sample item: "I am responsible for my success or failure in my career") and six-item scale, respectively (sample item: "I navigate my own career based on my personal priorities, as opposed to my employer's priorities"). As far as boundaryless career attitudes are concerned, they were also assessed based on Briscoe et al.'s (2006) measures, as follows: an eight-item 


\begin{tabular}{lccc}
\hline & Women & Men & Total \\
\hline Average age & 28.31 & 30.6 & 30.95 \\
Organizational size (\%) & & & \\
$\quad$ Small companies & 55.17 & 12.7 & 44 \\
$\quad$ Middle-size companies & 13.79 & 58.73 & 13.34 \\
$\quad$ Large companies & 31.04 & & 42.66 \\
Position (\%) & & 25.4 & 47.33 \\
$\quad$ Low & 63.22 & 42.85 & 37.33 \\
Middle & 33.33 & 31.75 & 15.34 \\
$\quad$ High & 3.45 & & 2 \\
Sector (\%) & & & 25.4 \\
$\quad$ Agriculture & 3.45 & 14.29 & 9.33 \\
Industry & 26.44 & 60.31 & 62.67 \\
$\quad$ Building & 5.75 & $12.42(\mathrm{SD}=6.95)$ & $9.91(\mathrm{SD}=6.86)$ \\
$\quad$ Service & 64.36 & $7.31(\mathrm{SD}=6.26)$ & $5.20(\mathrm{SD}=5.44)$ \\
Professional experience & 8.09 (SD $=6.22)$ & & \\
Organizational tenure & 3.76 (SD $=4.21)$ & & \\
& & & \\
\hline
\end{tabular}

scale was used to assess BM (sample item: "I seek job assignments that allow me to learn something new") and a five-item scale to measure OMP (sample item: "I like the predictability that comes from working continuously for the same organization").

Subjective career success refers to individuals' feelings of accomplishment and satisfaction with their careers. In the careers literature, career satisfaction - a person's positive emotional state resulting from a personal evaluation of his or her career experiences - is commonly used as an indicator of subjective career success. Therefore, subjective career success was assessed using Greenhaus et al.'s (1990) five-item career satisfaction scale (sample item: "I am satisfied with the success I have achieved in my career"). Information on demographic and background characteristics was collected to gain a deeper understanding of the composition of the sample. Demographic and background characteristics that were considered relevant to the present study included: gender, education level, professional experience, and organizational tenure.

\section{Procedure}

Data of this research were collected by means of a questionnaire sent to the sample study. The original questionnaires constructed in English were translated into Spanish, the language of the targeted population, following a translation - back translation procedure (Nunnally and Bernstein, 1994). Moreover, five cognitive interviews were conducted in order to ensure an accurate interpretation of the questionnaire items, as this technique allows understanding how respondents perceive and interpret questions, and to identify potential problems that may arise in prospective survey questionnaires (Drennan, 2003). Cognitive interviews permitted us interpreting which items are beyond the theoretical framework of the constructs to be analyzed (Collins, 2003; Jobe and Mingway, 1989). By means of verbal probing and thinking aloud (Drennan, 2003; Williamson et al., 2000), participants were asked to verbalize their interpretation of items and to paraphrase and/or comment on the wording of items in an effort to identify ambiguous or poorly worded questions. Once collected the data, they were processed following Miles and Huberman's (1994) suggestions. More specifically, the interviewees 
were asked to comment on the clarity and readability of the each item by asserting why they assessed it with a certain punctuation, and which parts of the items they found difficult to answer or interpret. Based on their comments, minor stylistic and semantic changes were made.

\section{Results}

Internal consistency was measured by Cronbach's $\alpha$ coefficient and the reliability estimates were acceptable and higher than 0.70 (internal consistencies for SD attitudes scale were 0.74 and 0.76 for VD career attitudes, respectively). The internal consistencies for the boundaryless career attitudes were also acceptable and similar to those supported by Briscoe et al. (2006) (BM, $\alpha=0.85$ and OMP $\alpha=0.75$ ).

The reliability analysis conducted for the career satisfaction scale yielded to an $\alpha$ coefficient of 0.87 . Correlation analyses were performed to examine the inter-correlations among the variables included in this study. Subjective career success was significantly related to self-direction and $\mathrm{OMP}(r=0.21, p<0.05 ; r=-0.20, p<0.05)$. OMP was significantly related to tenure and BM $(r=-0.19, p<0.05 ; r=0.30, p<0.01)$. Self-direction was also significantly related to VD and BM $(r=0.39, p<0.01 ; r=0.27$, $p<0.01)$. VD was significantly related with BM and $\mathrm{OMP}(r=0.22, p<0.01 ; r=0.18$, $p<0.05)$ (Table II).

The hypotheses considered have been contrasted by means of a model of structural equations. The proposed models suggest a reasonable fit to the data (Figures 1 and 2). The existence of the moderating effect of gender has been examined using the analytical strategy described by Singh (1995). The $\chi^{2}$ statistics for the unconstrained and constrained models are, respectively, 1,544.366 $(\mathrm{df}=908)$ and 1,554.272 $(\mathrm{df}=912)$. Their difference is 9.906 with four degrees of freedom. The significant difference (at the 5 percent level) indicates that the moderating effects do exist.

As far as specific relations in the hypotheses are concerned, we notice that in the case of women, self-direction has a positive effect upon subjective career success $(\beta=1.227$, $p<0.001$ ), while reliance upon their own values has a negative relation with their perceived career success $(\beta=-0.688, p<0.05)$. In the case of men, we found that OMP contributes negatively to psychological career success $(\beta=-0.262, p<0.1)$. The other relationships proposed have not been statistically significant. Hence, $H 2$ and $H 3$ were supported, and $H 1$ and $H 4$ were rejected.

\section{Discussion and conclusions}

This paper was aimed at analyzing gender differences in the relation between protean and boundaryless career attitudes and subjective career success, in today's dynamic organizational context. A potential limitation of this study is that all participants were distance learning-students, thus limiting the generalizability of the findings to other populations (more heterogeneous in terms of age and educational background). Furthermore, research should use longitudinal designs that permit more pertinent conclusions regarding the causal direction of the observed relationships and in-depth interviews to better understand the motives behind men's and women's subjective career success in a boundaryless and protean career setting.

The analysis indicates that women's career success is positively related with self-direction and negatively related with their reliance on their own values. Although Hall (2004) suggests that gender is not related to a person's career attitude, 


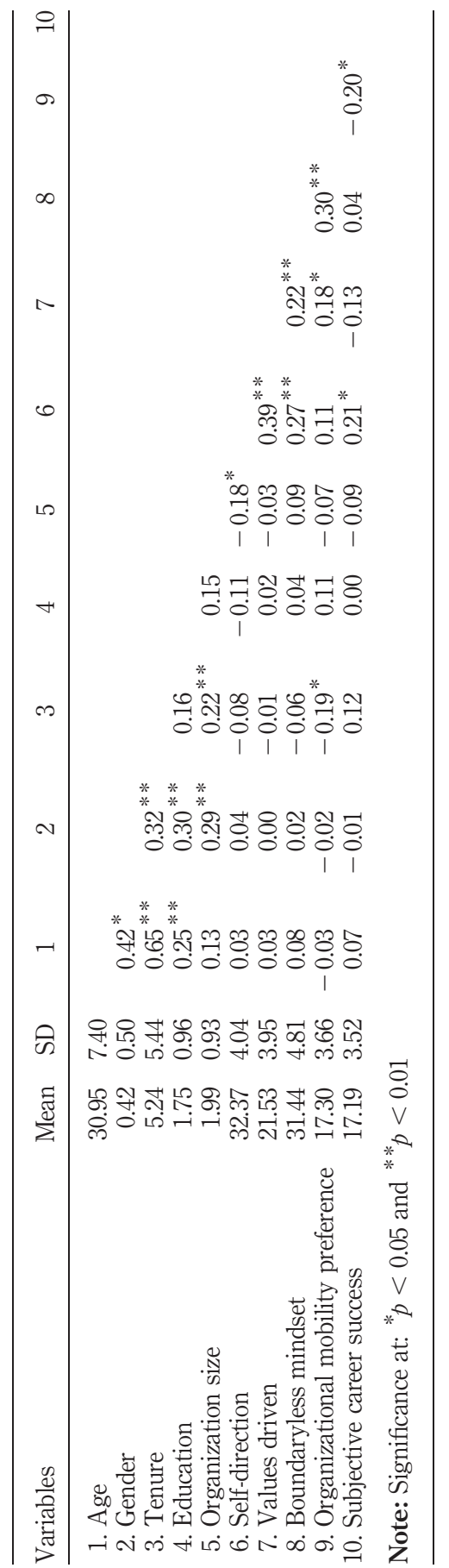




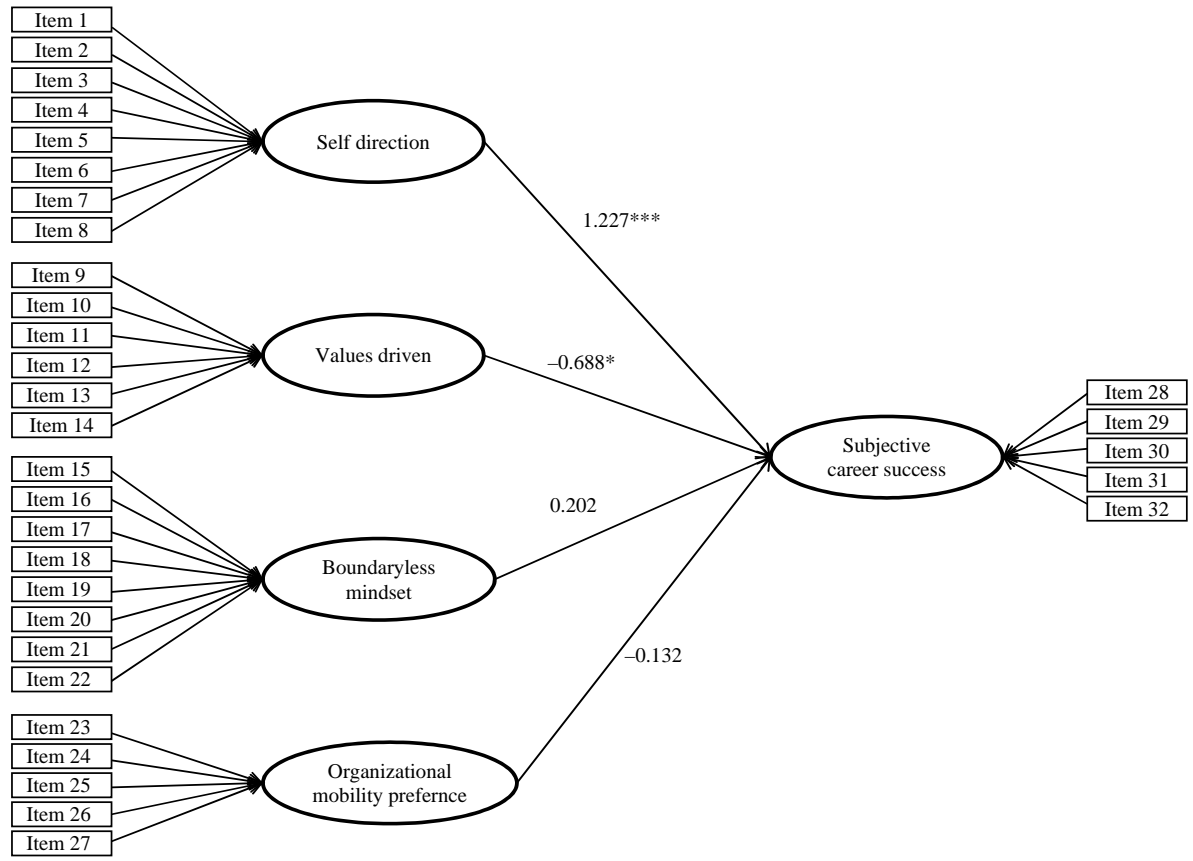

Notes: Significance at: ${ }^{*} \mathrm{p}<0.05,{ }^{* *} \mathrm{p}<0.01,{ }^{* * *} \mathrm{p}<0.001 ; \chi^{2}=736.330$;

$\mathrm{df}=454 ;$ RMSEA $=0.085$

several researchers (Cabrera, 2009; Sullivan and Mainero, 2008; Shapiro et al., 2008) have found that women are increasingly embracing more non-traditional careers. In comparing the costs and benefits of pursuing a traditional career, many women, especially mothers, decide that the cost of advancing to a higher level within the organization is too high (Grady and McCarthy, 2008). As Cabrera (2009, p. 88) remarks:

[. . .] most organizations are still based on the traditional view that the ideal worker should not let outside responsibilities interfere with hours on or commitment to work. This profile does not fit the reality of women's lives, due to the large amount of their non-work obligations.

Opposed to traditional careers, protean careers are more discontinuous, involving multiple career cycles, marked by self-direction and personal values congruence (Briscoe $e t$ al., 2006). Shapiro et al. (2008) indicate that many women are choosing to be "career self-agents" rejecting the traditional "work is primary" model and no longer are acting as employees working at the mandates of their employers but rather setting their own terms of employment. As a result, organizations that want to attract and retain talented women should reshape work structures and human resources policies and provide career models that allow women flexibility so that they could fulfill their work and non-work responsibilities and acquire a greater control over their working hours (Cabrera, 2009).

With respect to VD and their negative impact upon women's perceived career success, the results were surprising, as they did not support the existing literature's predictions that emphasize women's reliance on self-defined values (Cabrera, 2009). The values that typically drive protean careers are: being engaged in work that makes 


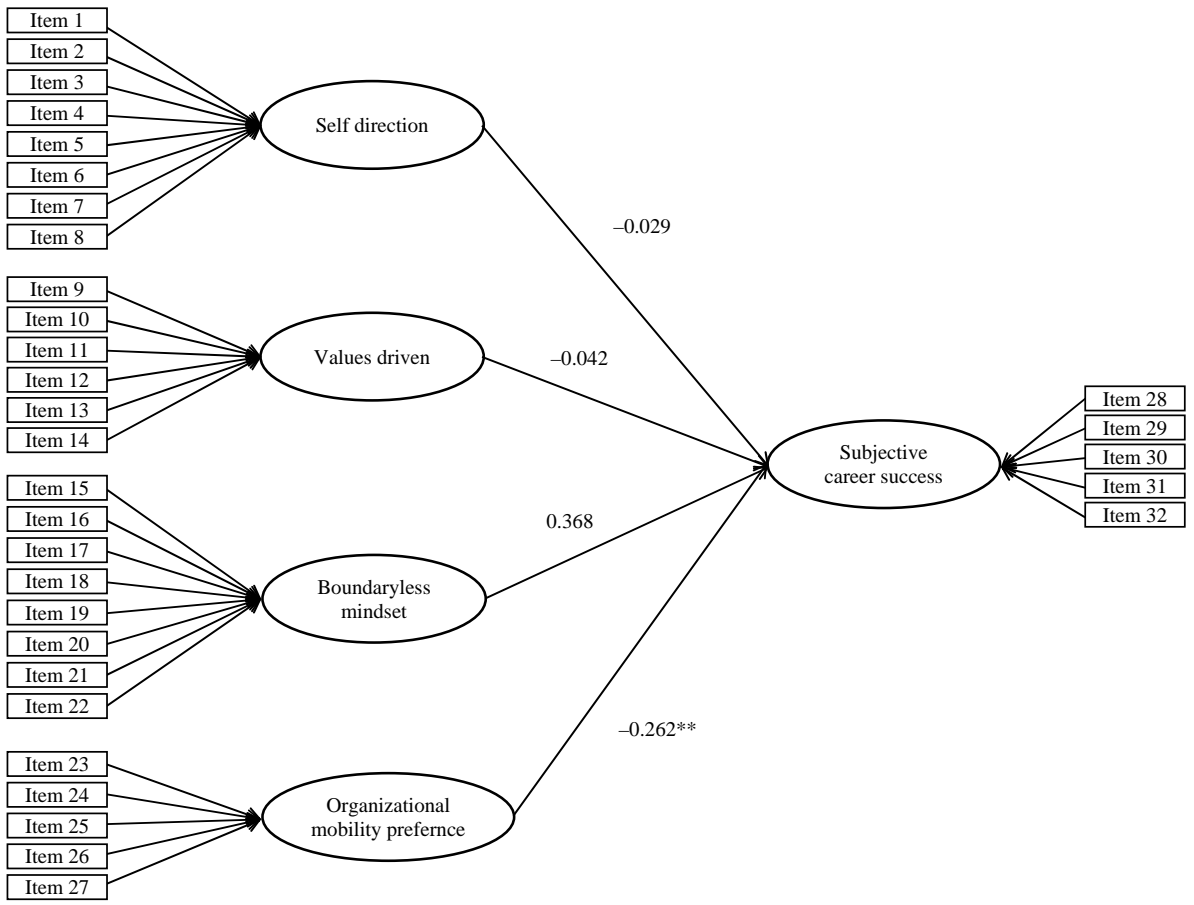

Notes: Significance at: $* \mathrm{p}<0.05, * * \mathrm{p}<0.01$, ***p $<0.001 ; \chi^{2}=807.323$;

$\mathrm{df}=454 ;$ RMSEA $=0.112$

a contribution to society and achieving work-life balance (Sargent and Domberger, 2007). However, we observe that the scale used to measure reliance on one's personal values in this study is very general, and it manly emphasize lack of congruence with organizational values. The findings of this study show that VD predisposition may lead to low levels of perceived career success. Alternatively, that relationship may be moderated by the degree of values fit between organizational and personal values. O'Reilly et al. (1991) showed that the fit of people's values to the values of their employing organization predicts individual satisfaction, commitment, turnover, and performance. This suggests that a high VD individual is likely to achieve subjective career success when his or her values match organizational values. Thus, the values fit might act as a moderator of the relationship between VD and subjective career success. Highly protean individuals are characterized by their desire to achieve meaningful outcomes, driven by strong personal values, and it is to be expected that when those individuals do not find a strong value fit with their employing organization, they are less likely to derive satisfaction when personally evaluating their career experiences. Therefore, the negative relationship between VD predispositions and subjective career success could be explained through the lack of value fit between individual values and organizational ones. However, this research does not focus on value match and has not analyzed in depth this construct, although we believe that this relationship deserves closer attention. Hence, future research is encouraged for examining the moderating effect of values match upon the relationship between VD predispositions and subjective career success. 
Finally, the research findings revealed a negative relation between OMP and men' subjective career success, suggesting that men are likely to change organizations or to look for employment beyond organizational boundaries when they are not satisfied with the conditions provided by the current organization or when they find a better offer in the external market. For the women sample, this relation was not statistically significant. In that sense, Inceologu et al.'s (2008) asserted that women are less driven by objective measures of career success such as money, status, and promotion and more by job security and are choosing the kind of career that enables them to be successful on their own terms, to find their balance (Heslin, 2005). However, a recent review and trans-disciplinary analysis on managing the maternal body found that women's choices tend to be drastically limited compared to their male equivalents. Specifically, women may be assessed negatively as workers based upon whether or not they have children, in a manner which does not apply to men. Gatrell (2011) observes how employers associate maternity (employed pregnant and post-birth women) with poor work-place performance, low work orientation, compromised health and unreability. Women with children may thus be obliged to establish their own career routes as a consequence of feel unsupported by colleagues and employers - not merely being a matter of choice. In addition, women managers may need to find their own career paths due the scarcity of women in top leadership, and thus, to the lack of role models as they could not break the glass ceiling. Tlaiss and Kauser (2010) observe that a number of studies have identified organizational barriers that prevent women from advancing such as constraining societal and cultural practices (Benson and Yukongdi, 2006; Wilson, 2003), discriminatory gender-specific factors (Parker and Fagenson, 1994; Powell, 2000), the anti-female nature of organizations (Cortis and Cassar, 2005; Eagly and Carli, 2007; Weir, 2003), and institutional discrimination such as limited access to networking processes, lack of mentoring, and limited training and development opportunities (Cordano et al., 2002; Lahtinen and Wilson, 1994).

BM was found to be unrelated with subjective career success, suggesting that only a predisposition to promote and sustain active relationship with individuals both within and across organizational boundaries is not sufficient for individuals to enhance their internal satisfaction with their careers. However, we suggest that future research should examine whether subjective career success is enhanced when this mindset is translated into a concrete behavior oriented at creating work-related relationships across department or organizational boundaries and at sustaining and enlarging one's relational network.

\section{References}

Agarwala, T. (2008), "Factors influencing career choice of management students in India", Career Development International, Vol. 13, pp. 362-76.

Arthur, M.B. (1994), "The boundaryless career - a new perspective for organizational inquiry", Journal of Organizational Behavior, Vol. 15 No. 4, pp. 295-306.

Arthur, M.B. and Rousseau, D.M. (1996), The Boundaryless Career: A New Employment Principle for a New Organizational Era, Oxford University Press, New York, NY.

Arthur, M.B., Inkson, K. and Pringle, J.K. (1999), The New Careers: Individual Action and Economic Change, Sage, London.

Baruch, Y. (2004), Managing Careers: Theory and Practice, Prentice-Hall, Harlow. 
Benson, J. and Yukongdi, V. (2006), “Asian women managers: participation, barriers, and future perspectives", in Yukongdi, V. and Benson, J. (Eds), Women in Asian Management, Routledge, London, pp. 141-51.

Blau, F.D., Ferber, M.A. and Winkler, A.E. (2002), The Economics of Women, Men and Work, 4th ed., Prentice-Hall, Upper Saddle River, NJ.

Briscoe, J.P. and Hall, D.T. (2006), "The interplay of boundaryless and protean careers: combinations and implications", Journal of Vocational Behavior, Vol. 69 No. 1, pp. 4-18.

Briscoe, J.P., Hall, D.T. and DeMuth, R.L.F. (2006), "Protean and boundaryless careers: an empirical exploration", Journal of Vocational Behavior, Vol. 69 No. 1, pp. 30-47.

Cabrera, E.F. (2009), "Protean organizations: reshaping work and careers to retain female talent", Career Development International, Vol. 14 No. 2, pp. 186-201.

Cappelli, P. (1999), “Career jobs are dead", California Management Review, Vol. 42 No. 1, pp. 146-67.

Collins, D. (2003), "Pretesting survey instruments: an overview of cognitive methods", Quality of Life Research, Vol. 12, pp. 229-38.

Cordano, M., Scherer, R. and Owen, C. (2002), "Attitudes toward women as managers: sex versus culture”, Women in Management Review, Vol. 17 No. 2, pp. 51-60.

Cortis, R. and Cassar, V. (2005), "Perceptions of and about women as managers: investigating job involvement, self-esteem and attitudes", Women in Management Review, Vol. 20 No. 3, pp. $149-64$.

Crant, J.M. (2000), "Proactive behavior in organizations", Journal of Management, Vol. 26, pp. 435-62.

DeFillippi, R.J. and Arthur, M.B. (1996), "Boundaryless contexts and careers: a competency-based perspective", in Arthur, M.B. and Rousseau, D.M. (Eds), The Boundaryless Career, Oxford University Press, New York, NY.

Drennan, J. (2003), "Cognitive interviewing: verbal data in the design and pretesting of questionnaires", Journal of Advanced Nursing, Vol. 42, pp. 57-63.

Eagly, A.H. and Carli, A.L. (2007), "Women and the labyrinth of leadership", Harvard Business Review, Vol. 85 No. 9, pp. 63-71.

Eby, L.T., Butts, M. and Lockwood, A. (2003), "Predictors of success in the era of the boundaryless career”, Journal of Organizational Behavior, Vol. 24, pp. 689-708.

Feldman, D.C. and Ng, T.W.H. (2007), "Careers: mobility, embeddedness, and success", Journal of Management, Vol. 33 No. 3, pp. 350-77.

Gatrell, C. (2011), "Managing the maternal body: a comprehensive review and transdisciplinary analysis", International Journal of Management Reviews, Vol. 13, pp. 97-112.

Grady, G. and McCarthy, A.M. (2008), "Work-life integration: experiences of mid-career professional working mothers", Journal of Managerial Psychology, Vol. 23 No. 5, pp. 599-622.

Gratton, L. and Ghoshal, S. (2003), "Managing personal human capital: new ethos for the 'volunteer' employee”, European Management Journal, Vol. 21, pp. 1-10.

Greenhaus, J.H. (2002), “Career dynamics”, in Borman, W.C., Ilgenand, D.R. and Klimoski, R.J.(Eds), Comprehensive Handbook of Psychology, Vol. 12, Wiley, New York, NY.

Greenhaus, J.H., Parasuraman, S. and Wormley, W.M. (1990), "Effects of race on organizational experiences, job-performance evaluations and career outcomes", Academy of Management Journal, Vol. 33, pp. 64-86.

Hall, D.T. (1976), Careers in Organizations, Sage, Thousand Oaks, CA. 
Hall, D.T. (2002), Protean Careers in and Out of Organizations, Sage, Thousand Oaks, CA.

Hall, D.T. (2004), “The protean career: a quarter-century journey”, Journal of Vocational Behavior, Vol. 65 No. 1, pp. 1-13.

Hall, D.T. and Chandler, D.E. (2005), "Psychological success: when the career is a calling", Journal of Organizational Behavior, Vol. 26 No. 2, pp. 155-76.

Hall, D.T., Gardner, W. and Baugh, S.G. (2008), "The questions we ask about authenticity and attainability: how do values and beliefs influence our career decisions?", Careers division theme session panel discussion presented at the Academy of Management, Anaheim, CA.

Heslin, P.A. (2005), "Experiencing career success”, Organizational Dynamics, Vol. 34 No. 4, pp. 376-90.

Inceoglu, I., Segers, J., Bartram, D. and Vloeberghs, D. (2008), "Age differences in work motivation", paper presented at the 23rd Annual Conference of the Society for Industrial and Organizational Psychology, San Francisco, CA.

Jobe, J.B. and Mingay, D.J. (1989), “Cognitive research improves questionnaires”, American Journal of Public Health, Vol. 79, pp. 1053-5.

Jones, C. (1996), "Careers in project networks: the case of the film industry", in Arthur, M.B. and Rousseau, D.M. (Eds), The Boundaryless Career, Oxford University Press, New York, NY, pp. 58-75.

King, Z. (2004), “Career self-management: its nature, causes and consequences”, Journal of Vocational Behavior, Vol. 65 No. 1, pp. 112-33.

Lahtinen, H. and Wilson, F. (1994), "Women and power in organizations”, Executive Development, Vol. 7 No. 3, pp. 16-23.

Lam, S.S.K. and Dreher, G.F. (2004), "Gender, extra-firm mobility and compensation attainment in the United States and Hong Kong”, Journal of Organizational Behavior, Vol. 25, pp. 791-805.

Levinson, D. (1978), The Seasons of a Man's Life, Knopf, New York, NY.

Lirio, P., Lituchy, T.R., Monserrat, S.I., Olivas-Lujan, M.R., Duffy, J., Fox, S., Gregory, A., Punnett, B.J. and Santos, N. (2007), "Exploring career-life success and family social support of successful women in Canada, Argentina, and Mexico", Career Development International, Vol. 12 No. 1, pp. 28-50.

Lykes, M.B. (1985), "Gender and individualistic vs. colectivistic bases for notions about the self", Journal of Personality, Vol. 53, pp. 356-83.

Mainiero, L.A. and Sullivan, S.E. (2005), "Kaleidoscope careers: an alternate explanation for the 'opt-out' revolution”, Academy of Management Executive, Vol. 19 No. 1, pp. 106-23.

Miles, M.B. and Huberman, A. (1994), Qualitative Data Analysis: An Expanded Sourcebook, Sage, Newbury Park, CA.

Mirvis, P.H. and Hall, D.T. (1994), "Psychological success and the boundaryless career", Journal of Organizational Behavior, Vol. 15 No. 4, pp. 365-80.

Ng, E.S.W., Burke, R.J. and Fiksenbaum, L. (2008), "Career choice in management: findings from US MBA students”, Career Development International, Vol. 13, pp. 346-61.

Ng, T.W.H., Eby, L.T., Sorensen, K.L. and Feldman, D.C. (2005), "Predictors of objective and subjective career success: a meta-analysis”, Personnel Psychology, Vol. 58 No. 2, pp. 367-408.

Nunnally, J.C. and Bernstein, I.H. (1994), Psychometric Theory, 3rd ed., McGraw-Hill, New York, NY. 
O'Reilly, C.A., Chatman, J. and Caldwell, D.F. (1991), "People and organizational culture - a profile comparison approach to assessing person-organization fit", Academy of Management Journal, Vol. 34, pp. 487-516.

Pachilicz, S., Schmitt, N. and Kuljanin, G. (2008), "A model of career success: a longitudinal study of emergency physicians”, Journal of Vocational Behavior, Vol. 73 No. 2, pp. 242-53.

Parker, B. and Fagenson, E.A. (1994), "An introductory overview of women in corporate management", in Davidson, M.J. and Burke, R.J. (Eds), Women in Management: Current Research Issues, Paul Chapman, London.

Parker, H. and Arthur, M.B. (2000), "Careers, organizing, and community", in Peiperl, M.A., Arthur, M.B., Goffee, R. and Morris, T. (Eds), Career Frontiers: New Conceptions of Working Lives, Oxford University Press, Oxford, pp. 99-121.

Powell, G.N. (2000), "The glass ceiling: explaining the good and bad news", in Davidson, M. and Borke, R. (Eds), Women in Management: Current Research Issues, Sage, London.

Powell, W.W. and Snellman, K. (2004), "The knowledge economy", Annual Review of Sociology, Vol. 30, pp. 199-220.

Prince-Gibbson, E. and Schwartz, S.H. (1998), "Value priorities and gender", Social Psychology Quarterly, Vol. 61 No. 1, pp. 49-67.

Rousseau, D.M. (1989), "Psychological and implied contracts in organizations", Employee Responsibilities \& Rights Journal, Vol. 2 No. 2, pp. 121-39.

Rousseau, D.M. and Wade-Benzoni, K.A. (1995), "Changing individual-organization attachments: a two way street", in Howard, A. (Ed.), Changing Nature of Work, Jossey-Bass, San Francisco, CA, pp. 290-321.

Sargent, L.D. and Domberger, S.R. (2007), "Exploring the development of a protean career orientation: values and image violations", Career Development International, Vol. 12 No. 6, pp. $545-64$.

Saxenian, A.L. (1996), "Beyond boundaries: open labor markets and learning in Silicon Valley", in Arthur, M.B. and Rousseau, D.M. (Eds), The Boundaryless Career, Oxford University Press, New York, NY, pp. 23-39.

Segers, J., Inceoglu, I., Vloberghs, D., Bartram, D. and Henderickx, E. (2008), "Protean and boundaryless careers: a study of potential motivators", Journal of Vocational Behavior, Vol. 73, pp. 212-30.

Seibert, S.E., Kraimer, M.L. and Crant, J.M. (2001), "What do proactive people do? A longitudinal model linking proactive personality and career success”, Personnel Psychology, Vol. 54, pp. 845-74.

Shapiro, M., Ingols, C. and Blake-Beard, S. (2008), "Confronting career double blinds: implications for women, organizations, and career practitioners", Journal of Career Development, Vol. 34 No. 3, pp. 309-33.

Singh, J. (1995), "Measurement issues in cross-national research", Journal of International Business Studies, Vol. 26, pp. 597-619.

Sturges, J. (1999), "What it means to succeed: personal conceptions of career success held by male and female managers at different ages", British Journal of Management, Vol. 10, pp. 239-52.

Sullivan, S.E. (1999), "The changing nature of careers: a review and research agenda", Journal of Management, Vol. 25, pp. 457-84.

Sullivan, S.E. (2010), "Self-direction in the boundaryless career era", in Hartung, P. and Subich, L. (Eds), Construction of Self in Career: Theory and Practice, APA Books, New York, NY. 
Sullivan, S.E. and Arthur, M.B. (2006), "The evolution of the boundaryless career concept: examining physical and psychological mobility", Journal of Vocational Behavior, Vol. 69 No. 1, pp. 19-29.

Sullivan, S.E. and Mainero, L. (2008), "Using the kaleidoscope career model to understand the changing patterns of women's careers: designing HRD programs that attract and retain women", Advances in Developing Human Resources, Vol. 10 No. 1, pp. 32-49.

Sullivan, S.N. and Baruch, Y. (2009), "Advances in career theory and research: critical review and agenda for future exploration”, Journal of Management, Vol. 35 No. 6, pp. 1452-571.

Super, D. (1957), Psychology of Careers, Harper \& Brothers, New York, NY.

Tharenou, P. (2009), "Self-initiated international careers: gender difference and career outcomes", in Baugh, S.G. and Sullivan, S.E. (Eds), Maintaining Energy, Focus and Options over the Career: Research in Careers, Vol. 1, Information Age, Charlotte, NC, pp. 197-226.

Tlaiss, H. and Kauser, S. (2010), "Perceived organizational barriers to women's career advancement in Lebanon", Gender in Management, Vol. 25 No. 6, pp. $462-96$.

Valcour, P.M. and Ladge, J.J. (2008), "Family and career path characteristics as predictors of women's career success outcomes”, Journal of Vocational Behavior, Vol. 73 No. 2, pp. 300-9.

Valcour, P.M. and Tolbert, P.S. (2003), "Gender, family and career in the era of boundarylessness: determinants and effects of intra- and inter-organizational mobility", International Journal of Human Resource Management, Vol. 14 No. 5, pp. 768-87.

Warr, P. (2008), "Work values: some demographic and cultural correlates", Journal of Occupational \& Organizational Psychology, Vol. 81, pp. 751-75.

Weir, D.T. (2003), "Human resource development in the Arab Middle East: a fourth paradigm", in Lee, M. (Ed.), HRD in a Complex World, Routledge, London, pp. 69-82.

Williamson, J., Ranyard, R. and Cuthbert, L. (2000), "A conversation-based process tracing method for use with naturalistic decisions: an evaluation study", British Journal of Psychology, Vol. 91, pp. 203-21.

Wilson, F.M. (2003), Organizational Behavior and Gender, 2nd ed., Ashgate, Aldershot.

Wise, A.J. and Millward, L.J. (2005), "The experiences of voluntary career change in 30-somethings and implications for guidance", Career Development International, Vol. 10 No. 5, pp. 400-17.

\section{Further reading}

Chatman, J.A. (1989), "Improving interactional organizational research - a model of person-organization fit”, Academy of Management Review, Vol. 14, pp. 333-49.

Pallant, J. (2001), SPSS Survival Manual, Open University Press, Milton Keynes.

Tabachnick, B.G. and Fidell, L.S. (1996), Using Multivariate Statistics, 3rd ed., Harper Collins, New York, NY.

\section{About the authors}

Mihaela Enache is an Assistant Lecturer at the Department of Business Administration, BARCELONA TECH (Escuela Técnica Superior de Ingenierías Industrial y Aeronáutica de Terrassa/ETSEIAT). She holds a BBA in Business Administration (Academy of Economic Studies, Bucharest) and a $\mathrm{PhD}$ degree in Business Administration (Universitat Politècnica de Catalunya). Her research interests include career management and organizational behavior. She is Co-editor of Journal of Industrial Engineering and Management. Mihaela Enache is the corresponding author and can be contacted at: mihaela.enache@upc.edu 
Jose M. Sallan is an Assistant Professor at the Department of Business Administration, BARCELONA TECH (Escuela Técnica Superior de Ingenierías Industrial y Aeronáutica de Terrassa/ETSEIAT). He holds a BBA in Industrial Engineering and a PhD degree in Business Administration (Universitat Politècnica de Catalunya). His research interests include intellectual capital and organizational behavior. He is Co-editor of Intellectual Capital and Journal of Industrial Engineering and Management.

Pep Simo is a Lecturer at the Department of Business Administration, BARCELONA TECH (Escuela Técnica Superior de Ingenierías Industrial y Aeronáutica de Terrassa/ETSEIAT) and Assistant Professor at the Universitat Oberta de Catalunya. He holds a BBA in Industrial Engineering and $\mathrm{PhD}$ degree in Business Administration (Universitat Politècnica de Catalunya). His main scientific contributions were made in the field of intellectual capital and human resources. He is Co-editor of Intellectual Capital and Journal of Industrial Engineering and Management.

Vicenç Fernandez is a Collaborating Professor at the Department of Business Administration, BARCELONA TECH (Escuela Técnica Superior de Ingenierías Industrial y Aeronáutica de Terrassa/ETSEIAT). He holds a BBA in Telecommunications and a PhD degree in Business Administration (Universitat Politècnica de Catalunya). His research interests include intellectual capital, organizational behavior and communication. He is $\mathrm{Co}_{\text {-editor of Journal of Industrial }}$ Engineering and Management. 